\title{
Formulation of M.L.R Model for Correlating the Factors Responsible for Industrial Accidents with Severity of Accidents and Man Days Lost by Using XLSTAT
}

\author{
P R Gajbhiye*, Dr A C Waghmare**, Dr R H Parikh*** \\ *Asst.Prof., KDKCE, Nagpur, Email: g_pankaj123@rediffmail.com \\ ** Principal, U.C.O.E., Umred. \\ *** Principal, B.M.C.O.E., Buttibori.
}

\begin{abstract}
Industrial accidents proves to be more costly and thus efforts are made to lower them and enhance safety.Safety Management system is a proactive and systematic approach for identification, evaluation, mitigation, prevention and control of hazards that could occur as a result of failures in process, procedures, or equipment. Increasing industrial accidents, loss of life \& property, public scrutiny, statutory requirements, aging facilities and intense industrial processes, all contribute to a growing need for Safety Management Program to ensure safety and risk management. The proposed paper work envisages to minimize industrial accidents by identifying the various factors responsible for industrial accidents and developing the approximate model to correlate the causes of accidents with the severity and the man days lost.
\end{abstract}

\section{INTRODUCTION}

Safety management is an organizational function which ensures that all safety risk has been identified, accessed and satisfactorily mitigated.

Safety can be defined as the reduction of risk to the level that is as low as is reasonable practice. There are three imperatives for adopting a safety management system: Ethical, Legal and Financial.

Safety management is commonly understood as applying a set of principles, framework, process and measures to prevent accidents, injuries and other adverse consequences that may be caused by using a services or a product. It is thus very important to envisage the various factors associated with the severity of accidents and man days lost due to the industrial accident which has a huge effect of the cost as well.

Thus a detail study has been carried out to identify the factors and their impact on the severity and man days lost for industrial accidents.

\subsection{Identification of Factors Responsible For} Industrial Accidents and Data Formulation:

The factors responsible for industrial accidents were identified by referring to various text on industrial safety, research papers as given below. A 10-point scale is created for the various factors in consultation with the Industrial Safety Managers / professionals, Industry Personnel and Experts and others and their average is taken as a pointer for the factor.
A. Agency associated with injury (causing accident) (x1):

This is the important factors which are taken to be in to consideration for causing accidents. The agency is the object, substance or exposure which is most closely associated with the injury and which could have been made safer

\begin{tabular}{|l|l|l|}
\hline $\begin{array}{l}\text { Sr. } \\
\text { No }\end{array}$ & Agency Pointer \\
\hline 1 & Hand tools. & 8.4 \\
\hline 2 & $\begin{array}{l}\text { Boilers, Pipe and Pressure } \\
\text { apparatus, furnace. }\end{array}$ & 8.0 \\
\hline 3 & Machine, Pump, Prime mover. & 7.2 \\
\hline 4 & Elevator and hoisting apparatus. & 6.8 \\
\hline 5 & Handling apparatus. & 5.0 \\
\hline 6 & Conveyors. & 4.6 \\
\hline 7 & Electrical apparatus. & 4.2 \\
\hline 8 & Other working substances. & 3.6 \\
\hline 9 & $\begin{array}{l}\text { Mechanical power transmission } \\
\text { apparatus. }\end{array}$ & 3.0 \\
\hline
\end{tabular}

Table I: Factors for agency associated with injury

B: unsafe act (violation of a commonly accepted safe procedure ) (x2)

This is also an important factor which is violation of commonly accepted safe procedure which resulted in selected accident type.

\begin{tabular}{|l|l|l|}
\hline $\begin{array}{l}\text { Sr. } \\
\text { No }\end{array}$ & Unsafe act & Pointer \\
\hline 1 & $\begin{array}{l}\text { Failure to use safe attire or } \\
\text { personal protective devices. }\end{array}$ & 8.4 \\
\hline 2 & $\begin{array}{l}\text { Using unsafe equipment, hands } \\
\text { instead of equipment or equipment } \\
\text { unsafe. }\end{array}$ & 7.8 \\
\hline 3 & Taking unsafe position or posture. & 6.6 \\
\hline
\end{tabular}




\begin{tabular}{|l|l|l|}
\hline 4 & Unsafe loading, placing. & 6.4 \\
\hline 5 & $\begin{array}{l}\text { Working on moving or dangerous } \\
\text { equipment. }\end{array}$ & 6.0 \\
\hline 6 & $\begin{array}{l}\text { Operating without authority, } \\
\text { failure to secure or warn. }\end{array}$ & 5.6 \\
\hline 7 & Making safety device inoperative. & 5.2 \\
\hline 8 & $\begin{array}{l}\text { Operating as working at unsafe } \\
\text { speed. }\end{array}$ & 4.4 \\
\hline 9 & $\begin{array}{l}\text { Distracting, teasing, abusing, } \\
\text { startling and so on. }\end{array}$ & 3.1 \\
\hline
\end{tabular}

Table II: Factors associated with unsafe act

\section{C: Personal causes (x3)}

These are also called as behavioristic causes that is the mental and boldly characteristics which permitted or occasioned the selected unsafe act.

\begin{tabular}{|l|l|l|}
\hline $\begin{array}{l}\text { Sr. } \\
\text { No }\end{array}$ & Personal causes & Pointer \\
\hline 1 & Neglecting safety procedures & 8.4 \\
\hline 2 & Lack of safety awareness & 6.8 \\
\hline 3 & Inexperience in work (unskilled) & 6.2 \\
\hline 4 & Improper attitude & 5.8 \\
\hline 5 & Lack of knowledge or skill & 5.4 \\
\hline 6 & Physical or mental defect & 3.1 \\
\hline
\end{tabular}

Table III: Factors associated with personal.

\section{D: Environmental causes $(\mathbf{x} 4)$}

It is a condition of selected agency, which could and could have been guarded and corrected.

\begin{tabular}{|l|l|l|}
\hline $\begin{array}{l}\text { Sr. } \\
\text { No }\end{array}$ & Environmental causes & Pointer \\
\hline 1 & Unsafe procedure & 8.0 \\
\hline 2 & Improper guarding & 7.6 \\
\hline 3 & $\begin{array}{l}\text { Substance or equipment defective } \\
\text { through use or warn out }\end{array}$ & 6.4 \\
\hline 4 & $\begin{array}{l}\text { Substance or equipment defective } \\
\text { through design or construction }\end{array}$ & 5.0 \\
\hline 5 & $\begin{array}{l}\text { Improper dress or apparel (Labour } \\
\text { Negligence) }\end{array}$ & 4.8 \\
\hline 6 & Unsafe housekeeping facilities & 4.4 \\
\hline 7 & $\begin{array}{l}\text { Improper dress or apparel } \\
\text { (Management failure to provide) }\end{array}$ & 4.2 \\
\hline
\end{tabular}

Table IV: Factors associated with Enviornment.

\section{E: Nature of injuries (x5)}

These are the type of injury which has been caused due to accident to the personal.

\begin{tabular}{|l|l|l|}
\hline Sr. No & Nature of injuries & Pointer \\
\hline 1 & Cut & 8.4 \\
\hline 2 & Wound & 7.8 \\
\hline 3 & Burn & 5.8 \\
\hline 4 & Strain & 5.6 \\
\hline 5 & Fracture & 5.4 \\
\hline 6 & Eye affected & 5.0 \\
\hline 7 & Miscellaneous & 4.4 \\
\hline 8 & Nausea & 3.1 \\
\hline
\end{tabular}

Table V: Factors associated with nature of injury.
Dependent variable

\section{A: Severity of accident (y1)}

The severity of the accident depends upon the impact of the injury caused due to the accident.

\begin{tabular}{|l|l|l|}
\hline $\begin{array}{l}\text { Sr. } \\
\text { No }\end{array}$ & Severity of accident & Pointer \\
\hline 1 & Fatal & 10 \\
\hline 2 & Major with permanent disability & 9 \\
\hline 3 & Major with temporary disability & 8 \\
\hline 4 & Minor with hospitalization & 7 \\
\hline 5 & Minor without hospitalization & 6 \\
\hline 6 & $\begin{array}{l}\text { Minor without a day off.(First aid } \\
\text { injury) }\end{array}$ & 5 \\
\hline
\end{tabular}

Table VI: Severity of accident

\section{B: Man house lost (y2)}

The data for man hours lost is gathered from the Indian standards manual for accident severity, the nature of injury caused with reference to the number of man hours lost has been depicted in the table of their report and with information from consultation with doctors and industry personal. The scale has been formed as follows

\begin{tabular}{|l|l|l|}
\hline Sr. No & Man days lost & Pointer \\
\hline 1 & $2401-6000$ days & 10 \\
\hline 2 & $1201-2400$ days & 9 \\
\hline 3 & $361-1200$ days & 8 \\
\hline 4 & $181-360$ days & 7 \\
\hline 5 & $91-180$ days & 6 \\
\hline 6 & $31-90$ days & 5 \\
\hline 7 & $8-30$ days & 4 \\
\hline 8 & $2-7$ days & 3 \\
\hline 9 & Less than a day & 2 \\
\hline
\end{tabular}

Table VII: Man days lost.

\subsection{Data collections:}

The authenticated data of the industrial accidents has been gathered from various government agencies responsible for handling industrial accidents.

About 173 number of accidents which are recorded by the above are been taken for formulation of the model.

On the basis of the accident reports and other supporting documents and information the factors responsible for industrial accident along with the severity of the accidents and the man days lost are entered in the excel work sheet. The procedure of assigning the pointers to the factors responsible for industrial accident along with the severity of the accidents and the man days lost are analyzed and noted.

\subsection{Model formulation:}

The proposed research work attempts to establish the correlation between the causes of accident $(\mathrm{X} 1, \mathrm{X} 2, \mathrm{X} 3, \mathrm{X} 4, \mathrm{X} 5)$ with severity of the accident(Y1) and man days lost (Y2). 
The correlation between the independent variable i.e causes of accidents and the dependent variables i.e. severity and man days lost can be establish by formulating.

Multivariable Regression Model using XLSTAT. Analysis of collected data:

Analysis of collected data is carried out by using: Multivariable regression model using XLSTAT.

\section{MULTIVARIABLE REGRESSION MODEL USING XLSTAT.}

XLSTAT is a suite of statistical add-ins for Microsoft Excel that has been developed since 1993 by Addinsoft to enhance the analytical capabilities of Microsoft Excel. Since 2003, Addinsoft is a Microsoft partner and all the XLSTAT analytical add-ins are registered on the Office Marketplace.

The XLSTAT software relies on Microsoft Excel for the input of data and the display of results. This makes the software very convenient to share data and results. Computations are done using autonomous software components that are optimized for speed and efficiency. The XLSTAT results are benchmarked against other statistical packages so to always have reliable findings.

The Addinsoft statistics add-ins offer a wide range of statistical and data analysis functions, ranging from descriptive statistics to multivariate data analysis. Many statistical add-ins for MS Excel exist. However, XLSTAT is the one that offers the largest number of analytical options.

\subsection{Result analysis:}

On the basis of data collected, the multivariable regression model is developed using XL STAT.

Result obtained from multivariable regression model using XL STAT.

Correlation matrix: The correlation matrix shows the correlation among the factors $(X 1, X 2$, $\mathrm{X} 3, \mathrm{X} 4, \mathrm{X} 5)$ and severity of accidents (Y1). It measures the strength of relationship between two variables. From the matrix it is found that the unsafe factor has a strong relationship with the severity of accident and least relationship with environmental causes.

\begin{tabular}{|l|l|l|l|l|l|l|}
\hline & $\mathrm{X} 1$ & $\mathrm{X} 2$ & $\mathrm{X} 3$ & $\mathrm{X} 4$ & $\mathrm{X} 5$ & $\mathrm{Y} 1$ \\
\hline $\mathrm{X} 1$ & 1 & -0.239 & -0.04 & -0.327 & -0.01 & 0.098 \\
\hline $\mathrm{X} 2$ & -0.239 & 1 & 0.293 & 0.352 & -0.03 & 0.425 \\
\hline $\mathrm{X} 3$ & -0.04 & 0.293 & 1 & 0.222 & -0.065 & 0.079 \\
\hline $\mathrm{X} 4$ & -0.327 & 0.352 & 0.222 & 1 & 0.074 & -0.228 \\
\hline $\mathrm{X} 5$ & -0.01 & -0.03 & -0.065 & 0.074 & 1 & 0.046 \\
\hline $\mathrm{Y} 1$ & 0.098 & 0.425 & 0.079 & -0.228 & 0.046 & 1 \\
\hline
\end{tabular}

Table IX: Correlation matrix Y1.

\subsection{Regression of variable Y1:}

The regression analysis for severity of accidents(y1) is as follows: table displays the goodness of fit coefficients of the model. The $\mathrm{R}^{2}$ (coefficient of determination) indicates the $\%$ of variability of the dependent variable which is explained by the explanatory variables. The closer to 1 the $\mathrm{R}^{2}$ is, the better the fit.

\begin{tabular}{|l|l|}
\hline Observations & 173 \\
\hline Sum of weights & 173 \\
\hline $\mathrm{DF}$ & 167 \\
\hline $\mathrm{R}^{2}$ & 0.363 \\
\hline Adjusted $\mathrm{R}^{2}$ & 0.344 \\
\hline MSE & 4.286 \\
\hline
\end{tabular}

Equation of the model (Y1):

\begin{tabular}{|l|l|l|l|l|}
\hline Observation & Weight & Y1 & Pred(Y1) & Residual \\
\hline Obs1 & 1 & 5.000 & 4.578 & 0.422 \\
\hline Obs2 & 1 & 5.000 & 4.578 & 0.422 \\
\hline Obs3 & 1 & 5.000 & 3.879 & 1.121 \\
\hline Obs4 & 1 & 3.000 & 3.879 & -0.879 \\
\hline Obs5 & 1 & 3.000 & 3.879 & -0.879 \\
\hline Obs6 & 1 & 5.000 & 6.216 & -1.216 \\
\hline Obs7 & 1 & 10.000 & 6.591 & 3.409 \\
\hline Obs8 & 1 & 10.000 & 7.536 & 2.464 \\
\hline Obs9 & 1 & 5.000 & 3.879 & 1.121 \\
\hline Obs10 & 1 & 10.000 & 4.888 & 5.112 \\
\hline Obs11 & 1 & 10.000 & 6.603 & 3.397 \\
\hline Obs12 & 1 & 10.000 & 6.591 & 3.409 \\
\hline Obs13 & 1 & 8.000 & 5.265 & 2.735 \\
\hline Obs14 & 1 & 10.000 & 4.838 & 5.162 \\
\hline Obs15 & 1 & 8.000 & 7.850 & 0.150 \\
\hline Obs16 & 1 & 3.000 & 7.715 & -4.715 \\
\hline Obs17 & 1 & 10.000 & 5.029 & 4.971 \\
\hline Obs18 & 1 & 10.000 & 5.381 & 4.619 \\
\hline Obs19 & 1 & 10.000 & 5.381 & 4.619 \\
\hline Obs20 & 1 & 10.000 & 6.603 & 3.397 \\
\hline
\end{tabular}

Table IX: Actual and Predicted values for Y1.

$\mathrm{Y} 1=0.639+0.225 * \mathrm{X} 1+0.428 * \mathrm{X} 2+0.0112 * \mathrm{X} 3-$ $0.964 * X 4+0.149 * X 5$

The model for $\mathrm{Y} 1$ shows that the factors $\mathrm{X} 1, \mathrm{X} 2, \mathrm{X} 3$ and $\mathrm{X} 5$ has a positive effect on the severity of accidents $\mathrm{Y} 1$, except for the factor $\mathrm{X} 4$ which shows a negative effect.

\begin{tabular}{|l|l|l|l|l|l|l|}
\hline & $\mathrm{X} 1$ & $\mathrm{X} 2$ & $\mathrm{X} 3$ & $\mathrm{X} 4$ & $\mathrm{X} 5$ & $\mathrm{Y} 2$ \\
\hline $\mathrm{X} 1$ & 1 & -0.239 & -0.04 & -0.327 & -0.01 & 0.039 \\
\hline $\mathrm{X} 2$ & -0.239 & 1 & 0.293 & 0.352 & -0.03 & 0.453 \\
\hline $\mathrm{X} 3$ & -0.04 & 0.293 & 1 & 0.222 & -0.065 & 0.118 \\
\hline $\mathrm{X} 4$ & -0.327 & 0.352 & 0.222 & 1 & 0.074 & -0.186 \\
\hline $\mathrm{X} 5$ & -0.01 & -0.03 & -0.07 & 0.074 & 1 & 0.023 \\
\hline $\mathrm{Y} 1$ & 0.039 & 0.453 & 0.118 & -0.186 & 0.023 & 1 \\
\hline
\end{tabular}


The actual and predicted values for severity of accidents (Y1) is as shown along with the residuals.

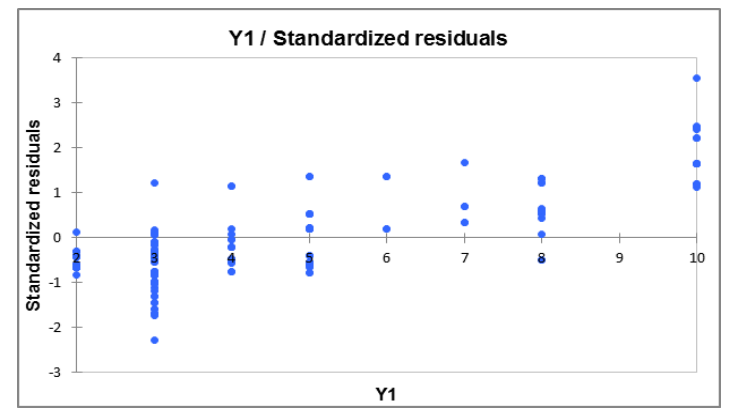

Fig:1: The plot shows the standardized residual with respect to $\mathrm{Y} 1$.

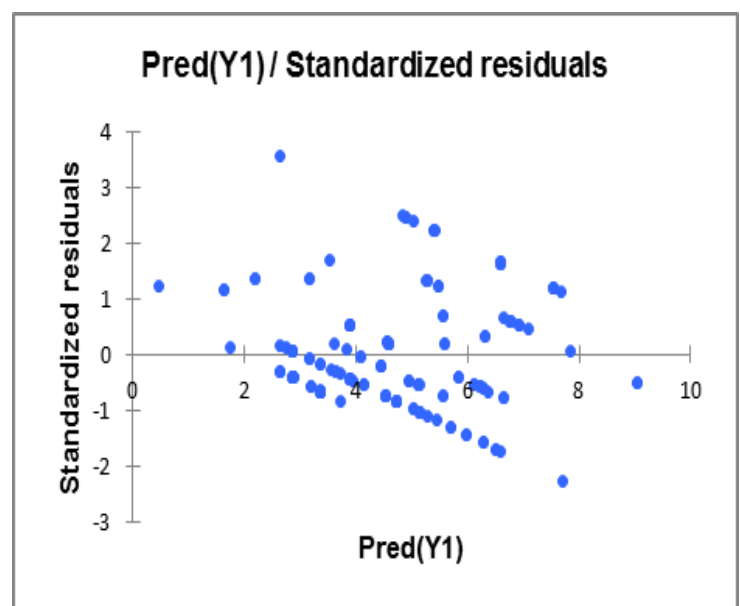

Fig:2 : The plot shows the standardized residuals with respect to predicted Y1

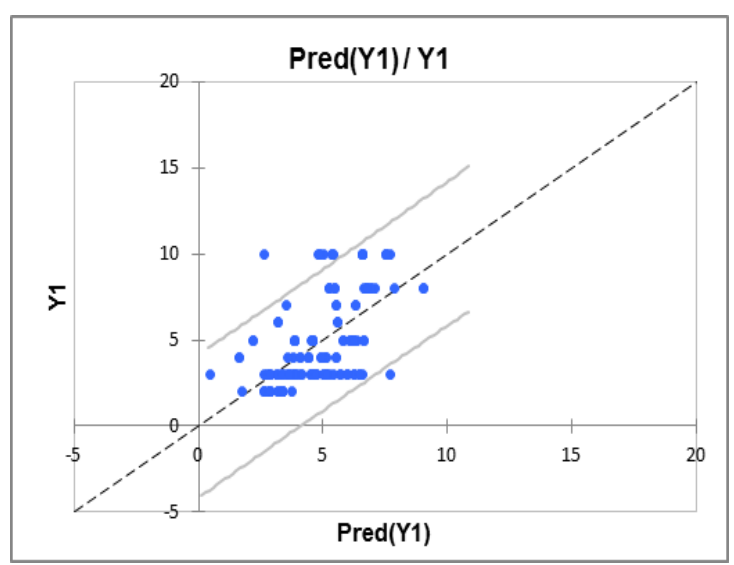

Fig:3 : Difference between the actual and predicted Y1.

The Correlation matrix: The correlation matrix shows the correlation among the factors $(\mathrm{X} 1, \mathrm{X} 2, \mathrm{X} 3$, $\mathrm{X} 4, \mathrm{X} 5)$ and Man days lost (Y2). It measures the strength of relationship between two variables. From the matrix it is found that the unsafe factor has a strong relationship with the man days lost and least relationship with environmental causes.
Table X: Correlation matrix Y2.

2.3 Regression of variable Y2: The regression analysis for man days lost(Y2) is as follows:

\begin{tabular}{|l|l|}
\hline Observations & 173 \\
\hline Sum of weights & 173 \\
\hline $\mathrm{DF}$ & 167 \\
\hline $\mathrm{R}^{2}$ & 0.351 \\
\hline Adjusted $\mathrm{R}^{2}$ & 0.332 \\
\hline MSE & 1.466 \\
\hline
\end{tabular}

Equation of the model (Y2):

Y2 $=8.016+0.068 * X 1+0.248 * X 2+0.042 * X 3-$ $0.531 * X 4+0.066 * X 5$

The model for Y2 shows that the factors $\mathrm{X} 1, \mathrm{X} 2, \mathrm{X} 3$ and $\mathrm{X} 5$ has a positive effect on the man days lost(Y2),except for the factor $\mathrm{X} 4$ which shows a negative effect.

The actual and predicted values for man days lost(Y2)is as shown along with the residuals.

\begin{tabular}{|l|l|l|l|l|}
\hline Observation & Weight & Y1 & Pred(Y1) & Residual \\
\hline Obs1 & 1 & 7.000 & 6.880 & 0.120 \\
\hline Obs2 & 1 & 7.000 & 6.880 & 0.120 \\
\hline Obs3 & 1 & 7.000 & 6.414 & 0.586 \\
\hline Obs4 & 1 & 7.000 & 6.414 & 0.586 \\
\hline Obs5 & 1 & 7.000 & 6.414 & 0.586 \\
\hline Obs6 & 1 & 7.000 & 7.571 & -0.571 \\
\hline Obs7 & 1 & 10.000 & 7.942 & 2.058 \\
\hline Obs8 & 1 & 10.000 & 8.355 & 1.645 \\
\hline Obs9 & 1 & 7.000 & 6.414 & 0.586 \\
\hline Obs10 & 1 & 10.000 & 6.818 & 3.182 \\
\hline Obs11 & 1 & 10.000 & 7.742 & 2.258 \\
\hline Obs12 & 1 & 10.000 & 7.942 & 2.058 \\
\hline Obs13 & 1 & 9.000 & 7.043 & 1.957 \\
\hline Obs14 & 1 & 10.000 & 6.868 & 3.132 \\
\hline Obs15 & 1 & 9.000 & 8.475 & 0.525 \\
\hline Obs16 & 1 & 7.000 & 8.434 & -1.434 \\
\hline Obs17 & 1 & 10.000 & 6.932 & 3.068 \\
\hline Obs18 & 1 & 10.000 & 7.109 & 2.891 \\
\hline Obs19 & 1 & 10.000 & 7.109 & 2.891 \\
\hline Obs20 & 1 & 10.000 & 7.742 & 2.258 \\
\hline
\end{tabular}

Predictions and residuals (Y2):

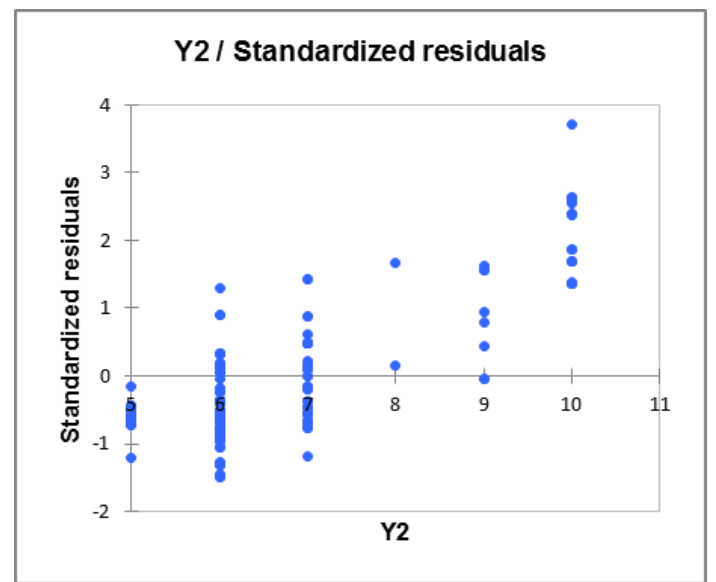

Fig:4: The plot shows the standardized residual with respect to $\mathrm{Y} 2$ 


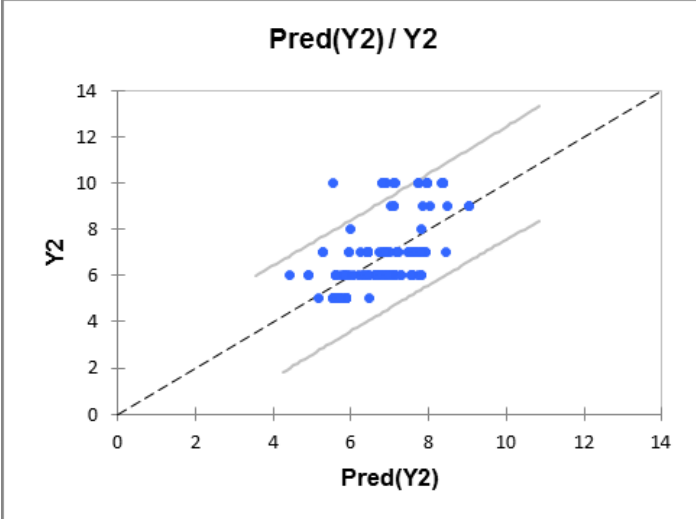

Fig:5: Difference between the actual and predicted Y2.

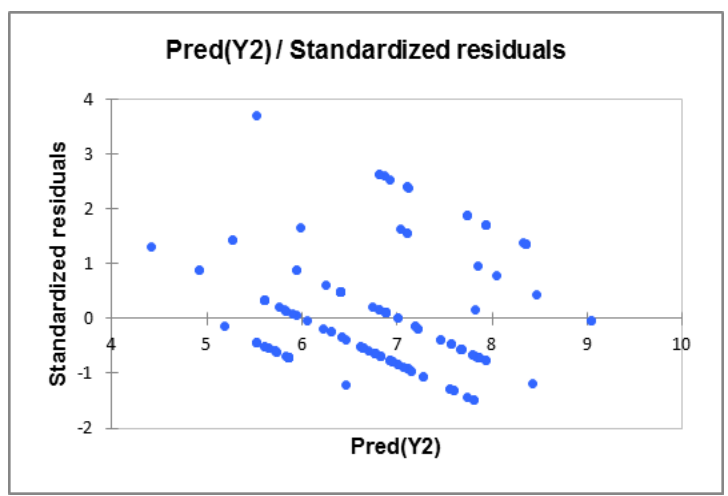

Fig:6 : The plot shows the standardized residuals with respect to predicted Y2.

\section{CONCLUSION}

The model is prepared for severity of the accidents (Y1) and the man days lost (Y).As it has been obsered that the regression value obtained from the multyvariable regression ansysis is 0.36 for $\mathrm{Y} 1$ and 0.35 for $\mathrm{Y} 2$ and the predicted values of the severity of the accidents (Y1) and the man days lost (Y2) are shown.

\section{REFERENCES}

[1]. R P Blake,(1943), "Industrial Safety", Prentice Hall, Inc, Englewood cliffs. N.J

[2]. H.W. Heinrich., "Industrial Accident Prevention", McGraw-Hill Book Company, Inc, New York.

[3]. Alexopoulos EC, "Introduction to Multivariate Regression Analysis", HIPPOKRATIA 2010, 14 ,23-28.

[4]. Paul Randy, "Applications of a Multiple Linear Regression Model to the Analysis of Relationships between Eastward- and Westward-Moving Intraseasonal Modes", Journal of Atmospheric Sciences, 2004, 3041-3048.
[5]. Cohen, H.H., 1983. Employee involvement: Its implications for improved safety management. Professional Safety 6, 30-35.

[6]. DeJoy, D.M., 1994. Managing safety in the workplace : An attributional theory analysis and model . Journal of Safety Research 25,3-17.

[7]. K. P. Moustris, P. T. Nastos, I. K. Larissi, and A. G. Paliatsos, "Application of Multiple Linear Regression Models and Artificial Neural Networks on the Surface Ozone Forecast in the Greater Athens Area, Greece", Advances in Meteorology Volume 2012, , 8 -16.

[8]. Hofmann, D.A., Stetzer, A., 1996. A crosslevel investigation of factors influencing unsafe behaviors and accidents. Personnel Psychology 49, 307-339.

[9]. Reber, R.A., Wallin, J., A., Chhokar, J.S., 1984. Reducing industrial accidents: A behavioral component. Industrial Relations 23, 119-125.

[10]. Shannon, H.S., Robson, L.S., Guastello, S.J., 1999. Methodological criteria for evaluating occupational safety intervention research. Safety Science 31, 161-179. 